\title{
PENGARUH CEKAMAN KEKERINGAN TERHADAP PERTUMBUHAN BERBAGAI GALUR SORGUM MUTAN BROWN MIDRIB SEBAGAI PAKAN TERNAK
}

\author{
Q. Aini, N. Jamarun, S. Sowmen, dan R. Sriagtula \\ Fakultas Peternakan Kampus Limau Manis Universitas Andalas, Padang 25163 \\ Email: aini.qurrata@gmail.com
}

\begin{abstract}
ABSTRAK
Penelitian ini bertujuan untuk mengetahui pengaruh dari cekaman kekeringan terhadap pertumbuhan beberapa jenis galur sorgum mutan Brown Midrib (BMR). Penelitian ini menggunakan metode eksperimen dengan Rancangan Acak Lengkap (RAL) pola faktorial (3×3) dengan 6 ulangan. Faktor A adalah jenis sorgum, terdiri dari: A1 (sorgum numbu), A2 (sorgum mutan BMR Bioss) dan A3 (sorgum mutan BMR G-63). Faktor B adalah kadar air tanah, terdiri dari: B1: 25\%, B2: 50\% dan B3: 75\%. Peubah yang diamati adalah: tinggi tanaman, diameter batang, jumlah daun, panjang daun dan lebar daun. Data yang diperoleh dianalisis dengan analisis ragam (ANOVA) menurut Steel and Torrie (1991), perbedaan antar perlakuan dilakukan uji lanjut Duncan Multiple Range Test (DMRT). Hasil penelitian memperlihatkan bahwa tidak terdapat interaksi antara jenis sorgum dan kadar air terhadap panjang daun, jumlah daun, diameter batang, tinggi tanaman dan tinggi batang. Interaksi hanya terdapat antara jenis sorgum dengan kadar air tanah terhadap lebar daun, dimana sorgum mutan BMR G-63 (A3) memiliki lebar daun lebih kecil pada B3 bila dibandingkan dengan jenis sorgum A1 dan A2 dimana terjadi peningkatan lebar daun. Dari penelitian ini dapat disimpulkan bahwa kadar air tanah 25\% sudah memberikan respon yang baik terhadap pertumbuhan sorgum mutan BMR.
\end{abstract}

Kata kunci: cekaman kekeringan, sorgum BMR, kadar air

\section{PENDAHULUAN}

Penyediaan hijauan berkualitas dan tersedia sepanjang waktu merupakan tantangan dalam usaha peternakan khususnya ternak ruminansia, karena hijauan merupakan bahan pakan utama ternak ruminansia dengan tingkat konsumsi mencapai $>80 \%$ dari total bahan kering (Abdullah, 2011). Masalah umum dalam budidaya ternak ruminansia adalah kekurangan pakan hijauan pada musim kemarau baik kualitas, kuantitas dan kontinuitas sehingga sulit untuk mewujudkan penyediaan pakan secara berkelanjutan. Untuk mengatasi masalah tersebut perlu dibudidayakan hijauan pakan dengan produksi biomasa yang tinggi dan tahan kering, salah satunya adalah tanaman sorgum. Sorgum merupakan spesies yang paling cocok untuk lingkungan yang rawan kekeringan (Fracasso et al., 2016).

Dewasa ini telah dikembangkan sorgum mutan Brown Midrib (BMR). Sorgum mutan BMR adalah hasil pemuliaan tanaman dengan teknik mutasi melalui iradiasi sinar gamma, secara genetik memiliki kandungan lignin lebih rendah dan kandungan nutrisi yang lebih tinggi dibanding sorgum Numbu (non BMR) (Oliver et al., 2005). Sorgum mutan BMR mengandung 9.28\% protein kasar dan $66.47 \%$ kecernaan bahan kering (Sriagtula, 2016). Kandungan lignin yang lebih rendah pada BMR ini diduga dapat mempengaruhi daya tahan tanaman sorgum terhadap kekeringan. Menurut Pedersen et al. (2005) lignin penting dalam transportasi air dan memelihara jaringan vaskular pada tanaman. Kandungan lignin yang lebih rendah memungkinkan tanaman mengalami kekurangan air, terutama pada musim kemarau karena ketersediaan air tanah yang berkurang. Akibatnya tanaman tidak mendapatkan asupan air yang mencukupi dan mengalami cekaman kekeringan.

Cekaman kekeringan merupakan salah satu faktor lingkungan yang berdampak sangat buruk terhadap pertumbuhan tanaman sehingga dapat menyebabkan penurunan produksi tanaman (JunFeng et al., 2010).

Berdasarkan pemikiran tersebut, dilakukan penelitian yang bertujuan untuk mengetahui bagaimana pengaruh cekaman kekeringan pada beberapa jenis sorgum mutan BMR ditinjau dari pertumbuhannya.

\section{MATERI DAN METODE}

Penelitian ini dilakukan di rumah kaca Fakultas Pertanian Universitas Andalas dengan menggunakan benih tiga (3) jenis sorgum yaitu sorgum Numbu (konvensional), sorgum mutan BMR Bioss dan sorgum mutan BMR G-63; tanah, pupuk kandang, polibag, ayakan, meteran, jangka 
sorong dan lain-lain. Penelitian ini menggunakan metode eksperimen dengan rancangan acak lengkap (RAL) pola faktorial $(3 \times 3)$ dengan 6 ulangan. Faktor A adalah jenis sorgum (A1: Sorgum Numbu, A2: Sorgum mutan BMR Bioss, A3: Sorgum mutan BMR G-63), dan Faktor B adalah kadar air tanah (B1: 25\%, B2: 50\%, B3: 75\%).

Media tanam yang digunakan adalah $20 \mathrm{~kg}$ tanah ditambah dengan pupuk kandang dan pupuk dasar $\mathrm{SP}_{3} 6, \mathrm{KCl}$ dan urea. Penanaman benih sorgum dilakukan dengan cara tugal pada lubang tanam. Perlakuan cekaman kekeringan dilakukan pada saat tanaman telah dipelihara sampai berumur satu bulan. Untuk mengetahui berapa jumlah air yang harus ditambahkan pada tiap polybag sesuai dengan perlakuan kadar air tanah dilakukan pengukuran kadar air media (tanah) pada kondisi kapasitas lapang.

Penentuan kapasitas lapang mengacu pada Hendriyani dan Setiari (2009). Pengukuran kapasitas lapang dilakukan dengan cara menyiapkan media tanam sebanyak $500 \mathrm{~g}$ dalam beberapa buah polibag, disiram dengan air sampai jenuh, kemudian didiamkan selama tiga hari sampai tidak ada lagi air yang menetes. Setelah tiga hari, ditimbang berat masing-masing polybag dan didapatkan berat basah (Tb). Selanjutnya tanah dioven dengan suhu $105^{\circ}$ C, selama 24 jam, sehingga didapatkan berat kering (Tk). Kemudian hitung kapasitas lapangnya dengan rumus

$$
\mathrm{IAI}=\frac{\mathrm{Tb}-\mathrm{Tk}}{\mathrm{Tk} \quad \text { (Islami dan Utomo, 1995) }}
$$

Hasil pengukuran kapasitas lapang tanah prapenelitian didapatkan nilai kapasitas lapang dari tanah yang akan digunakan adalah 37\%, sehingga untuk 100\% kapasitas lapang tanah $20 \mathrm{~kg}$ diperlukan air sebanyak $1480 \mathrm{ml}$. Pengambilan data pertumbuhan tanaman dilakukan pada saat panen.

\section{HASIL DAN PEMBAHASAN}

Pengaruh cekaman kekeringan terhadap pertumbuhan tanaman sorgum yang diteliti ditunjukkan pada Tabel 1.

Hasil analisis ragam menunjukkan bahwa secara umum tidak terjadi interaksi $(\mathrm{P}>0,05)$ antara jenis sorgum dengan kadar air tanah terhadap seluruh parameter tinggi tanaman, kecuali lebar daun. Faktor tunggal jenis sorgum (A) berpengaruh terhadap hampir seluruh parameter pertumbuhan sorgum kecuali lebar daun, sedangkan faktor kadar air tanah (B) secara umum tidak berpengaruh
Tabel 1. Rataan panjang daun $(\mathrm{cm})$, lebar daun $(\mathrm{cm})$, jumlah daun (helai), diameter batang $(\mathrm{mm})$ dan tinggi tanaman $(\mathrm{cm})$ beberapa jenis sorgum dengan kadar air tanah berbeda

\begin{tabular}{lcccccc}
\hline \multicolumn{1}{c}{ Peubah } & Faktor & B1 & B2 & B3 & Rataan & SEM \\
\hline Panjang & A1 & 93,73 & 90,83 & 95,82 & $93,46^{\mathrm{a}}$ & 7,26 \\
daun & A2 & 27,58 & 37,57 & 29,18 & $34,31^{\mathrm{b}}$ & \\
& A3 & 42,68 & 44,35 & 44,32 & $43,78^{\mathrm{b}}$ & \\
Lebar daun & Rataan & 54,67 & 57,58 & 56,44 & & \\
& A1 & $1,38^{\mathrm{b}}$ & $1,18^{\mathrm{b}}$ & $4,25^{\mathrm{a}}$ & 2,27 & 0,46 \\
& A2 & $0,98^{\mathrm{b}}$ & $1,53^{\mathrm{b}}$ & $4,25^{\mathrm{a}}$ & 2,26 & \\
& A3 & $1,57^{\mathrm{b}}$ & $1,82^{\mathrm{b}}$ & $1,47^{\mathrm{b}}$ & 1,62 & \\
Jumlah & Rataan & $1,31^{\mathrm{b}}$ & $1,51^{\mathrm{b}}$ & $3,32^{\mathrm{a}}$ & & \\
daun & A1 & 7,83 & 8,17 & 7,83 & $7,94^{\mathrm{a}}$ & 0,71 \\
& $\mathrm{~A} 2$ & 4,00 & $4,5 \mathrm{O}$ & 4,00 & $4,17^{\mathrm{b}}$ & \\
& $\mathrm{A} 3$ & 5,00 & 5,50 & 5,17 & $5,22^{\mathrm{b}}$ & \\
Diameter & Aataan & 5,61 & 6,06 & 5,67 & & \\
batang & A1 & 0,52 & 0,58 & 0,63 & $0,58^{\mathrm{a}}$ & 0,06 \\
& A2 & 0,17 & 0,27 & 0,22 & $0,22^{\mathrm{c}}$ & \\
& A3 & 0,32 & 0,37 & 0,28 & $0,32^{\mathrm{b}}$ & \\
Tinggi & Rataan & 0,33 & 0,41 & 0,38 & & \\
tanaman & A1 & 138,2 & 149,8 & 149,8 & $145,94^{\mathrm{a}}$ & 10,04 \\
& A2 & 30,6 & 40,9 & 39,4 & $36,97^{\mathrm{b}}$ & \\
& A3 & 47,3 & 48,8 & 52,1 & $49,38^{\mathrm{b}}$ & \\
& Rataan & 72,0 & 79,8 & 80,4 & & \\
\hline
\end{tabular}

Keterangan: huruf kecil yang berbeda pada baris dan kolom yang sama menunjukkan berbeda nyata $(P<0,05)$.

terhadap tinggi tanaman kecuali pada lebar daun. Jenis sorgum Numbu (A1) memiliki nilai pertumbuhan tanaman paling tinggi dibandingkan dengan jenis sorgum mutan BMR (A2 dan A3). Hal ini diduga karena sorgum Numbu memiliki daya tumbuh yang cukup cepat dibandingkan dengan jenis sorgum mutan yang merupakan hasil mutasi. Antara sorgum mutan BMR Bioss dan G-63 memiliki hasil pertumbuhan yang relatif sama kecuali pada diameter batang, diameter batang sorgum mutan BMR Bioss lebih kecil dibandingkan dengan G-63. Hal ini diasumsikan bahwa kedua jenis sorgum mutan BMR ini masih dalam masa adaptasi untuk pengembangan lebih lanjut.

Kadar air tanah yang tidak berpengaruh terhadap tinggi tanaman menunjukkan bahwa masing-masing jenis sorgum memiliki kemampuan adaptasi yang cukup tinggi terhadap cekaman kekeringan sehingga tidak terlalu menghambat laju pertumbuhan dari masing-masing sorgum. Hasil ini sesuai dengan Fracasso et al. (2016) yang menyatakan bahwa bila dibandingkan dengan tanaman sereal lainnya, sorgum merupakan spesies yang paling cocok untuk lingkungan yang rawan kekeringan.

Interaksi antara jenis sorgum (A) dan kadar air tanah (B) hanya terlihat pada peubah lebar daun. Semakin tinggi kadar air tanah maka ukuran lebar daun semakin besar kecuali pada jenis sorgum mutan BMR G-63 (A3), sedangkan pada kadar air tanah yang rendah 25\% (B1) umumnya ukuran 
lebar daun lebih kecil. Pengecilan ukuran lebar daun pada tanaman dengan kadar air yang rendah merupakan salah satu respon dalam menghadapi cekaman kekeringan. Hasil ini sesuai dengan Hussain et al. (2008) yang menyatakan bahwa mitosis yang terganggu (pemanjangan dan perluasan sel) mengakibatkan penurunan tinggi tanaman, luas daun, dan pertumbuhan pada tanaman yang mengalami kekeringan. Cekaman kekeringan dapat menghambat pertumbuhan tanaman, salah satunya dapat dilihat pada perluasan daun, penurunan luas daun merupakan respon pertama tanaman terhadap kekeringan (Taiz and Zeiger, 2002). Luas daun menurun selama cekaman kekeringan akibat melambatnya proses pembelahan sel dan ukuran daun tetap kecil untuk meminimalkan hilangnya evapotranspirasi (Bibi et. al., 2010).

\section{SIMPULAN}

Simpulan yang dapat diambil dari penelitian ini adalah kadar air tanah 25\% memberikan respon yang baik terhadap pertumbuhan sorgum mutan BMR.

\section{UCAPAN TERIMA KASIH}

Terima kasih kepada Fakultas Peternakan Unand yang telah memberikan dana penelitian ini melalui anggaran dana DIPA Fakultas Peternakan Universitas Andalas tahun anggaran 2017 dengan nomor kontrak 012/PPM/I/PNBP/Faterna-Unand/2017.

\section{DAFTAR PUSTAKA}

Abdullah, L. 2011. Pemikiran Pengembangan Sistem Pakan Nasional. Info Feed Volume 1, No.1, Maret 2011.

Bibi, A., H. A. Sadaqat, H. M. Akram and M. I. Mohammed. 2010. Physiological markers for screening Sorghum (Sorghum bicolorL.). Germplasm under water stress condition.Int.
J. Agric. Biol. 12(3): 451-455.

Fracasso, A., L. M. Trindade, S. 2016. Amaducci. Drought stress tolerance strategiesrevealed by RNA-Seq in two sorghumgenotypes with contrasting WUEBMC Plant Biology (2016) 16:115.

Hendriyani, I.S. dan N. Setiari. 2009. Kandungan klorofildan pertumbuhankacang panjang(Vigna sinemsis) pada tingkat penyediaan air yang berbeda. J. Sains dan Mat. 17(3): 145-150.

Hussain M., Malik M.A., Farooq M., Ashraf M.Y., Cheema M.A. 2008. Improving drought tolerance by exogenous application of glycinebetaine and salysilic acid in sunflower. J. Agron. Crop. Sci. 194: 193-199.

Islami, T. dan Utomo, W.H. 1995. Hubungan Tanah, Air dan Tanaman. IKIP. Semarang Press. Semarang.

Jun-Feng S, Guo MX, Lian JR, Xiaobin P, Guo WY, Ping CX. 2010. Gene expression profiles of response to water stress at the jointing stage in wheat. Agricultural Sciences in China 9(3): 323-330.

Oliver AL, Pedersen JF, Grant RJ, Klopfenstein TJ. 2005. Comparative effects of the sorghum bmr-6 and bmr-12 genes: I. Forage sorghum yield and quality. Crop Sci. 45, 2234-2239 Pedersen JF, Vogel KP, Funnell DL. 2005. Impact of reduced lignin on plant fitness. Crop Sci. 45, 812-819.

Sriagtula R. 2016. Evaluasi produksi, nilai nutrisi dan karakteristik serat galur sorgum mutan brown midrib sebagai bahan pakan ruminansia [Disertasi]. Bogor: Sekolah Pascasarjana, Institut Pertanian Bogor.

Steel RGD, Torrie JH. 1991. Prinsip dan Prosedur Statistika: Suatu Pendekatan Biometrik. Sumatri B, penerjemah. Jakarta: Gramedia. Terjemahan dari: Principles and Procedures of Statistics. Taiz L, Zeiger E. 2002. Plant Physiology. 3rd Ed. Sinauer Associates, Inc. 